\title{
Ice-flow features on Ice Stream B, Antarctica, revealed by SPOT HRV imagery
}

\author{
Carolyn J. Merry \\ Byrd Polar Research Center and Department of Civil Engineering, The Ohio State University, Columbus, Ohio 43210, U.S.A. \\ IAN M. WHILLANS \\ Byrd Polar Research Center and Department of Geological Sciences, The Ohio State University, Columbus, Ohio 43210, U.S.A.
}

\begin{abstract}
Numerous features of glaciological significance appear on two adjoining SPOT High Resolution Visible (HRV) images that cover the onset region of Ice Stream B, Antarctica. Many small-scale features, such as crevasses and drift plumes, have been observed in aerial photography. Subtle large-scale features, such as long flow traces that have not been mapped previously, are clear in the satellite imagery. Newly discovered features include ladder-like runners and rungs within certain shear margins, flow traces that are parallel to ice flow, unusual crevasse patterns and flow traces originating within shear margins.
\end{abstract}

\section{INTRODUCTION}

The use of satellite imagery is an effective means for mapping and studying polar ice sheets. In many cases the imagery has formed the basis for glaciological maps (e.g. Swithinbank, 1988; Stephenson and Bindschadler, 1990).

Numerous authors have recognized the benefits of using satellite imagery for glacier mapping. Flow traces, ice rises, ice rumples, crevasses and crevasse fields, and shear rifts are glacial features that are readily mapped by satellite (Martin, 1976; Orheim, 1978; Swithinbank and Lucchitta, 1986; Lucchitta and others, 1987; Stephenson and Bindschadler, 1990; Casassa and Turner, 1991; Casassa and others, 1991). Velocities can be measured if there is repeat imagery (Lucchitta and Ferguson, 1986; Bindschadler and Scambos, 1991; Tseng, 1992). Changes in ice extent along the Antarctic coast have been documented by several researchers (Ferrigno and Gould, 1987; Williams and Ferrigno, 1988). Imagery has been used to track icebergs (Swithinbank and others, 1977; Jacobs, 1988). Even wind-formed features can be recognized and used to indicate the route of katabatic flow (Bromwich and others, 1990). Potential blue-ice regions that may be meteorite-stranding surfaces can be identified (Williams and others, 1983; Lucchitta and others, 1987). Various snow types can be mapped and surface temperature inferred (Orheim and Lucchitta, $1987,1988)$. Brightness temperatures for various sectors of Antarctica have also been studied (Jezek and others, 1990, 1991). These studies demonstrate that there is great potential in studying the large ice sheets using satellite imagery.

If the genesis and evolution of observed ice features can be understood, it may be possible to use satellite images to infer the recent history and mechanics of the ice sheets, and to help in assessing their mass balance and stability. Developing such a capability motivates the present study. Imagery was obtained for a part of Ice Stream B, Antarctica, studied previously using aerial photography and ground-based surveys (Vornberger and Whillans, 1986, 1990; Whillans and others, 1987; Whillans and Bindschadler, 1988). The glacial features in the imagery are enhanced and described in an effort to deduce the genesis, preservation and significance of the features. Some of the features are also observed on aerial photographs, which have been studied and interpreted previously (Vornberger and Whillans, 1986, 1990). Moreover, this region has been intensively studied with airborne radio-echo sounding to produce elevation maps of the ice surface and bedrock surface (Shabtaie and others, 1987; Shabtaie and Bentley, 1988), and there are data on ice velocity (Whillans and others, 1987) and snow-accumulation rate (Whillans and Bindschadler, 1988).

\section{IMAGE ACQUISITION}

Most previous satellite studies of the Antarctic ice sheet have used Landsat Multispectral Scanner Subsystem (MSS) or Thematic Mapper (TM) imagery. Landsat cannot acquire images of Ice Stream B at $84^{\circ} \mathrm{S}$ because of the inclination of its orbit $\left(98.2^{\circ}\right.$, the angle of the orbital plane with the equatorial plane). Landsat can image the Earth only between $82^{\circ} \mathrm{N}$ and $82^{\circ} \mathrm{S}$. The comparable French satellite SPOT (Satellite Pour l'Observation de la Terre) has a similar orbital inclination of $98.7^{\circ}$, but has a pointable sensor that can acquire images up to $425 \mathrm{~km}$ on either side of nadir, or as far south as $86^{\circ} \mathrm{S}$.

Two neighboring panchromatic images were taken by 


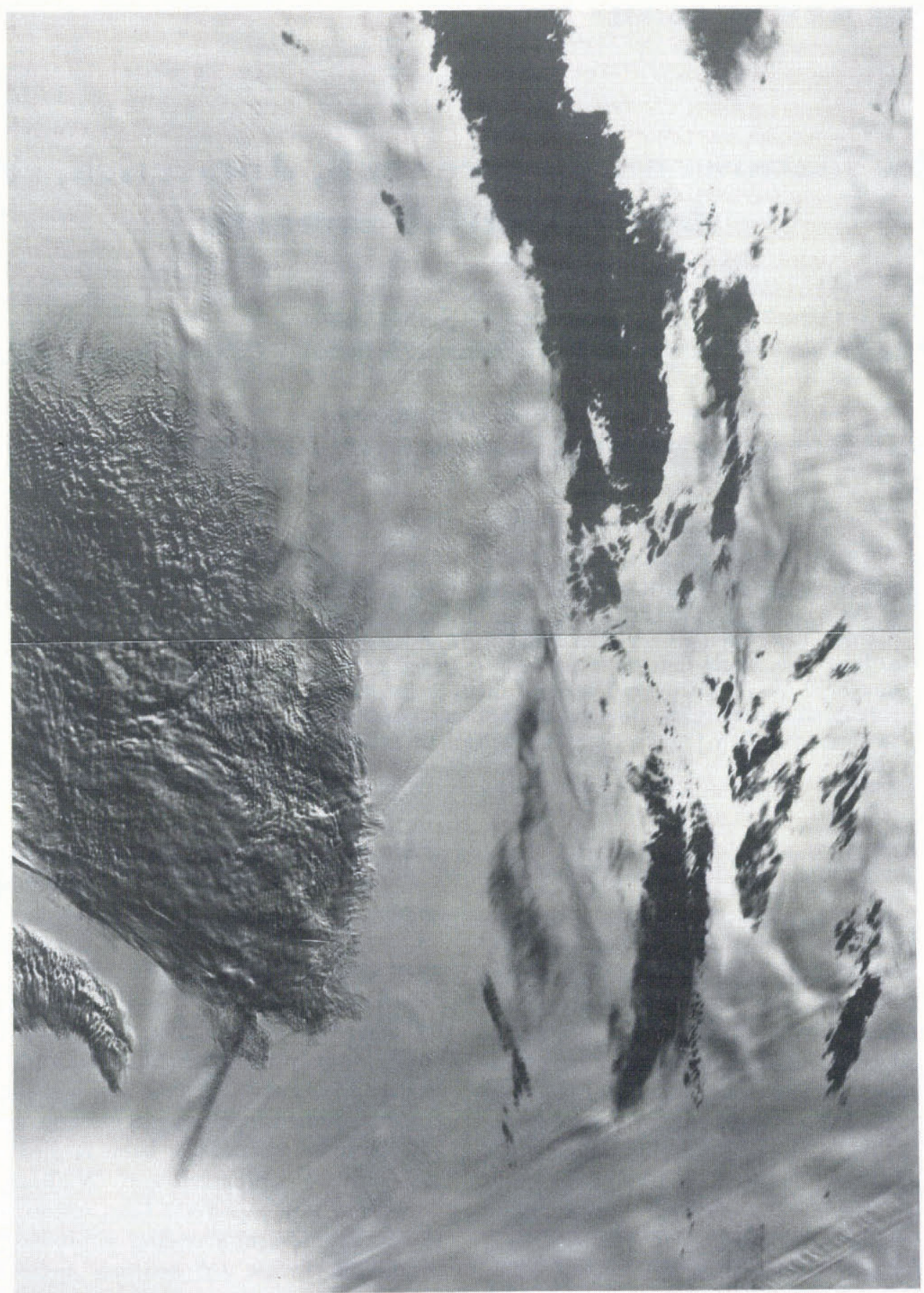

a

Fig. 1. a. Concatenated images of the onset region for Ice Stream B. The imagery was taken at 1627 h GMT (about $0630 \mathrm{~h}$ local time) on 5 February 1988 . The ground coverage is $81.8 \mathrm{~km}$ in the cross-track direction and $115.0 \mathrm{~km}$ in the along-track direction. In all figures, north is $47^{\circ}$ counterclockwise and solar illumination is $27^{\circ}$ clockwise from the top of the figure. The elevation of the sun is $18^{\circ}$. Viewing angle from the satellite is $30.9^{\circ}$ from nadir toward the southeast. The negative for this figure was produced at the NASA/Goddard Space Flight Center. The coordinates of the corners are: top

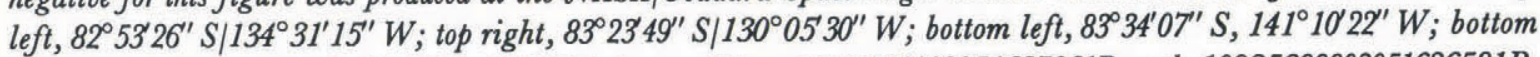
right, $84^{\circ} 07^{\prime} 53^{\prime \prime} S, 136^{\circ} 48^{\prime} 10^{\prime \prime} W$ (SPOT image IDs: $10915708802051627061 P$ and 10925688802051626581P, copyright SPOT Image Corporation).

SPOT of the onset region of Ice Stream B (Fig. la). The two images are continuous, being acquired in immediate sequence. So, for simplicity, the two images are concatenated and are discussed as one image. Because the region is south of the satellite orbit, the view is oblique. The pixels, as originally acquired, cover $13 \mathrm{~m}$ across-track and $10 \mathrm{~m}$ along-track. Pixel resampling to $10 \mathrm{~m}$ has been performed by SPOT Image Corporation.

The imagery was taken by the HRV (High Resolution
Visible) sensors on SPOT. These can operate in either panchromatic mode (spectral range $0.51-0.73 \mu \mathrm{m}$ ) with a $10 \mathrm{~m}$ nominal pixel size, or multispectral mode with a $20 \mathrm{~m}$ nominal pixel size. We selected the first mode because fine spatial resolution is needed to show best the crevasses.

The radiometric data have a resolution of $8 \mathrm{bits}$, providing a potential dynamic range of 256 grey levels. In our case, the major glaciological features in full sunshine 


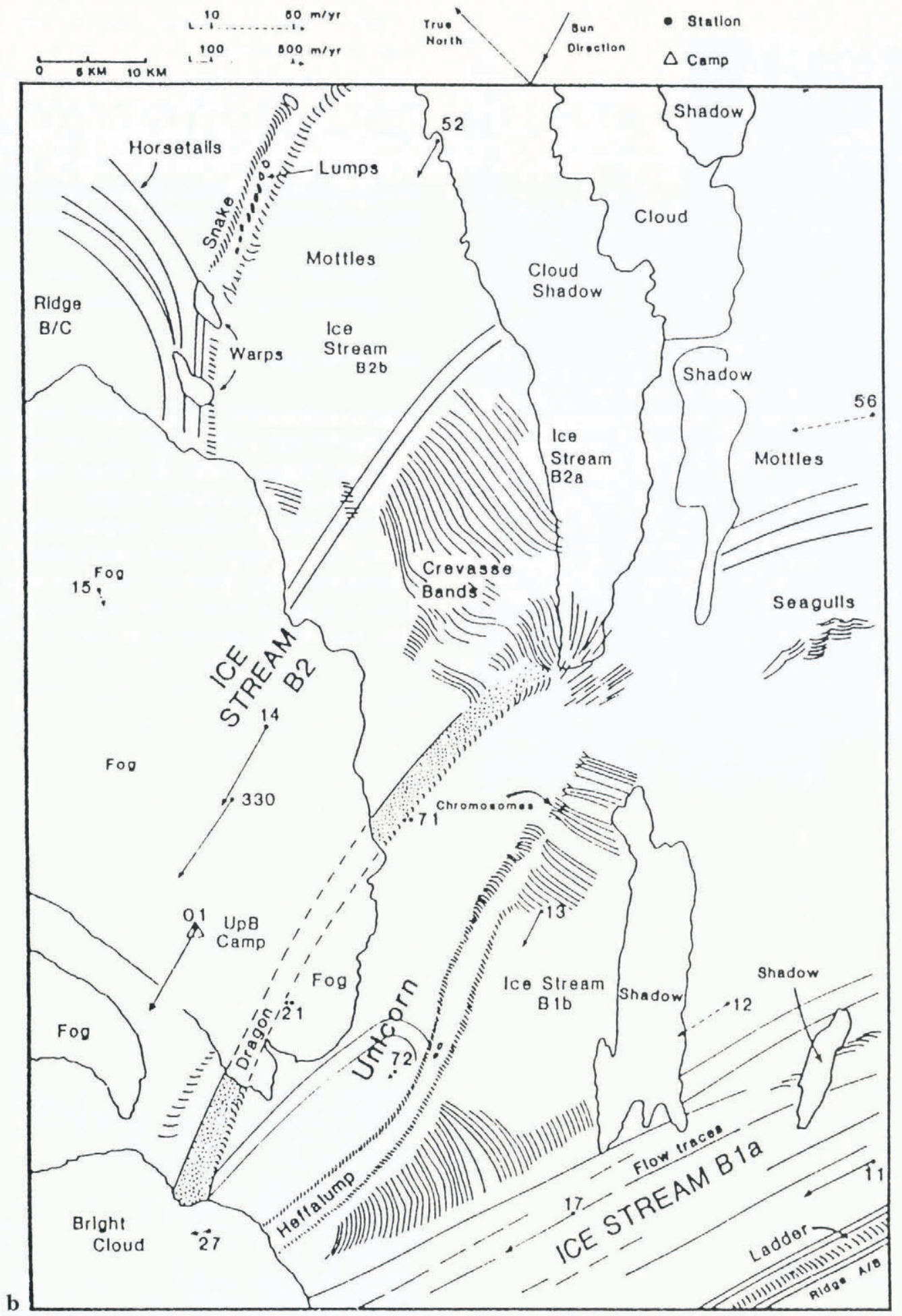

Fig. 1. b. Sketch map of Figure 1a, showing the major ice features mapped and described in the text. Bold numbers are station names. Velocity vectors are plotted at two scales, ice speed can be distinguished by dashed if slow and solid if fast. Positions and velocities are from McDonald (1990) and Whillans and Van der Veen (1993).

are represented by only ten grey levels. Glaciological features located in shadows from clouds result in an additional ten levels. As identified in Figure 1b, about half of the imagery shows cloud or cloud shadows. The image processing is designed to display only the glaciologically relevant grey levels.

\section{IMAGE PROGESSING}

Image contrast is enhanced by selecting the relevant brightness values to display or print. A contrast enhancement, termed histogram normalization, is used for printing the detailed sub-scenes. The algorithm reassigns the grey-level distribution to approximate a normal distribution of large dynamic range. Because the distribution of pixel values varies from sub-scene to subscene, a different enhancement is used for each sub-scene. As much as possible, sub-scenes are selected that are either fully in sunshine or in about the same level of cloud shadow. This enhancement procedure displays a maximum amount of information from the imagery because the greatest contrast enhancement is applied to the most populated range of brightness values (Jensen, 1986). The 


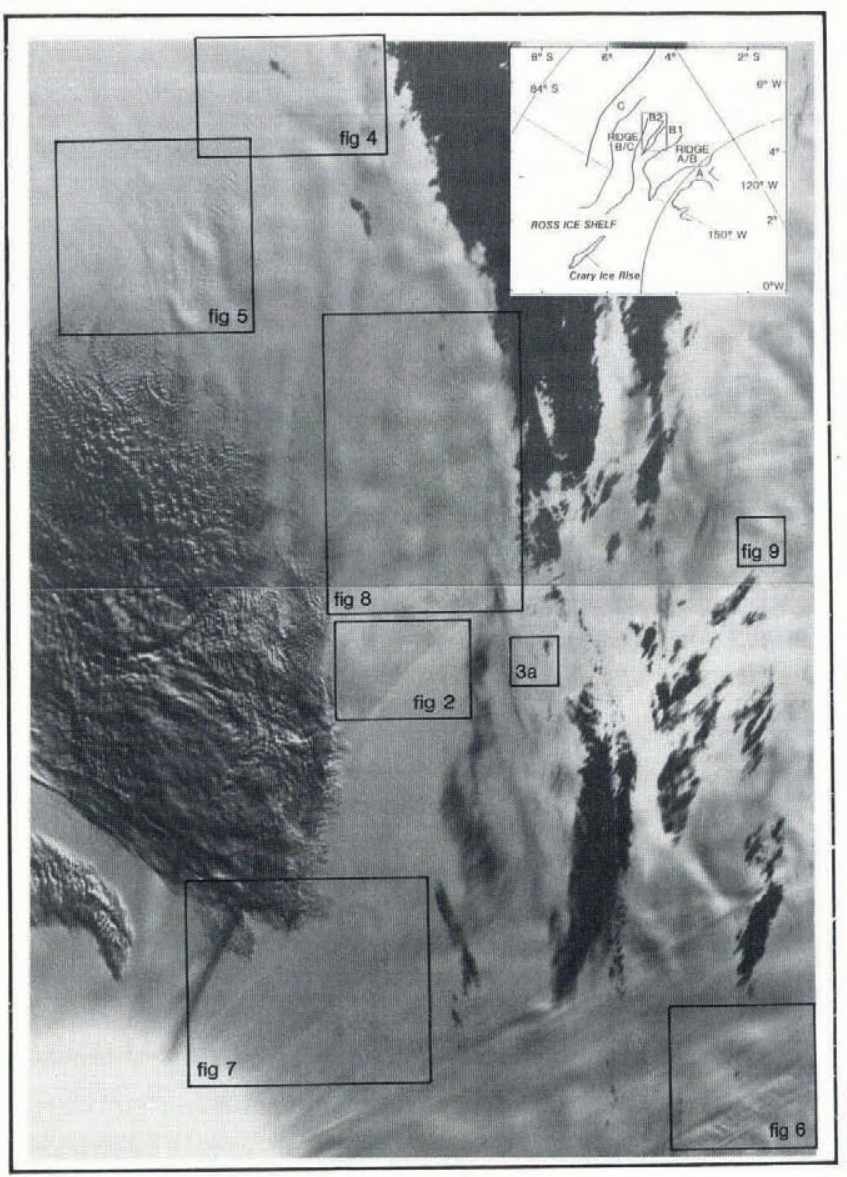

c

Fig. 1. c. Locations of sub-areas shown in subsequent figures. Inset shows location of images.

images were processed using MIPS (Micro Image Processing System) and printed on a Linotronic 300 printer.

The imagery covers regions that have been surveyed for measuring ice velocity and elevation. The ground stations cannot be seen on the imagery, but the velocity stations are marked on the imagery according to their coordinates and the coordinates of the images provided by SPOT Image Corporation. The image coordinates have a location accuracy of about $830 \mathrm{~m}$ (SPOT Image Corporation, 1987).

\section{GLACIAL FEATURES}

The major glacial features in the imagery are sketched in Figure 1b. The two principal tributaries of Ice Stream B are tributary B1, in the lower right, and tributary B2, left of center. They flow westward, from upper right to lower left in the figure. Between the tributaries is a nearly stagnant region called the "unicorn". Outside of the two large tributaries are slowly moving regions: "ridge $\mathrm{A} / \mathrm{B}$ " in the lower right and "ridge $B / C$ " in the upper left of the image.

The tributaries are further divided in Figure $1 \mathrm{~b}$. The major part of tributary Bl is called Bla. A wedge-shaped tributary between Bla and the unicorn is Blb. Another wedge-shaped tributary is called B2b.
Major strike-slip shear margins are clearly evident from the orientation and pattern of crevasses. The "snake" and the "dragon" are the margins of Ice Stream B2. The "heffalump" (another fearsome character invented by Milne (1926)) and "ladder" are newly named shear margins of Ice Stream B1. All shear margins are also detected by aerial photography (Vornberger and Whillans, 1986, 1990) and radar (Shabtaie and Bentley, 1988).

Parts of the imagery (Fig. 1c) have been selected for enlargement and discussion below.

\section{Shear margins}

Shear margins form the boundaries between fast-moving ice streams and nearly stagnant interstream ridges. Each long, curvilinear band of dense, intersecting surface crevasses indicates a shear margin.

A representative shear margin is shown in Figure 2. To the lower right is the slowly moving unicorn, an interstream ridge. Next to the more slowly moving ice there is a series of en échelon, hook-shaped crevasses. More toward the ice stream is a chaotic zone of crevasses. Still more toward the ice stream, the chaotic zone gives way to a relict chaotic zone. The upper left of the image covers the main body of the ice stream. In the far upper left, there are long, curving crevasses transverse to the flow direction (from upper right to lower left).

Ice flow in a shear zone has been modeled by Vornberger and Whillans (1990). Their model can account for the patterns observed on the imagery. The

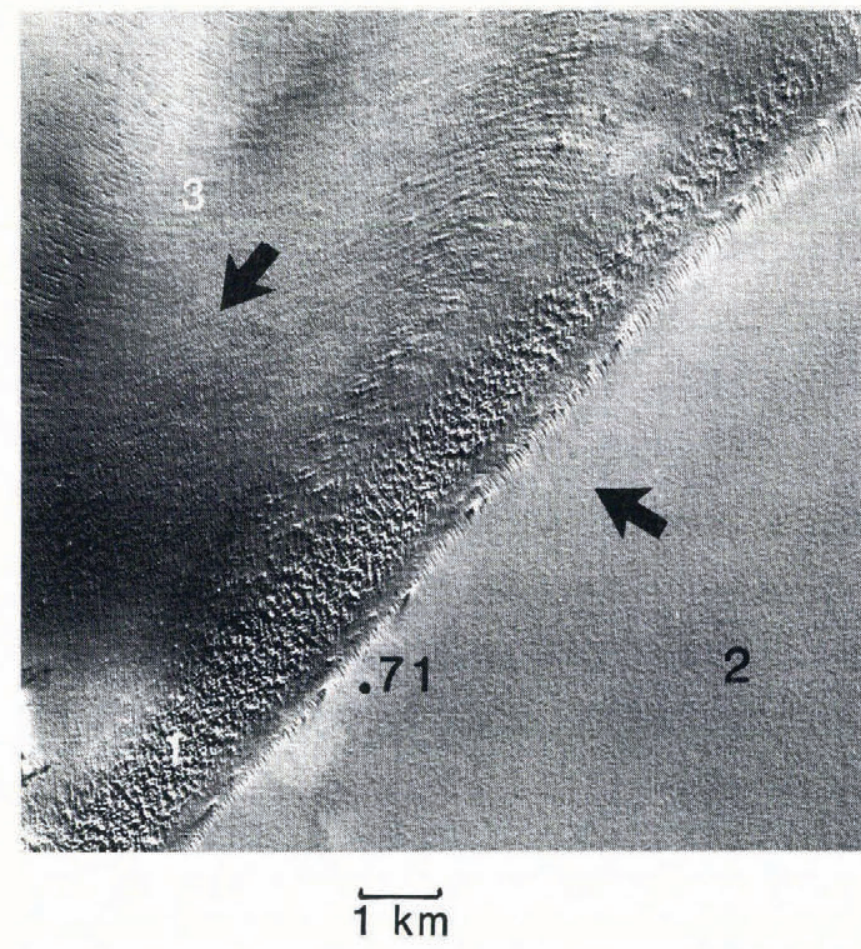

Fig. 2. The dragon, a left-lateral shear margin. Numbers label the dragon (1), the nearly stagnant unicorn (2), and Ice Stream B2 (3), which is moving at about 423 m year $^{-1}$. Station 71 , located on the unicorn, is moving at 3 myear $^{-1}$. The "knobs", which are most prominent among the hookshaped marginal crevasses, are drift plumes. Scene width is $10.24 \mathrm{~km}$. 
ice from the unicorn makes a sharp lefthand turn as it joins the ice stream. The first evidence of stress along its trajectory is the diagonally oriented crevasses. With progressive simple shear, these crevasses are bent into "hooks" that are concave down the ice stream. With subsequent rotation, shearing and formation of new crevasses, these hook-shaped crevasses can no longer be separately identified, and a complex jumble of intersecting crevasses, called the chaotic zone, results. Farther into the ice stream, the shearing is less intense, and the chaotic ice becomes partly buried by fresh snow. This area is the relict chaotic zone. Still farther inward is the ice stream proper, where transverse crevasses usually dominate. The transverse crevasses may have been rotated by simple shear so that they are now concave down-flow. This

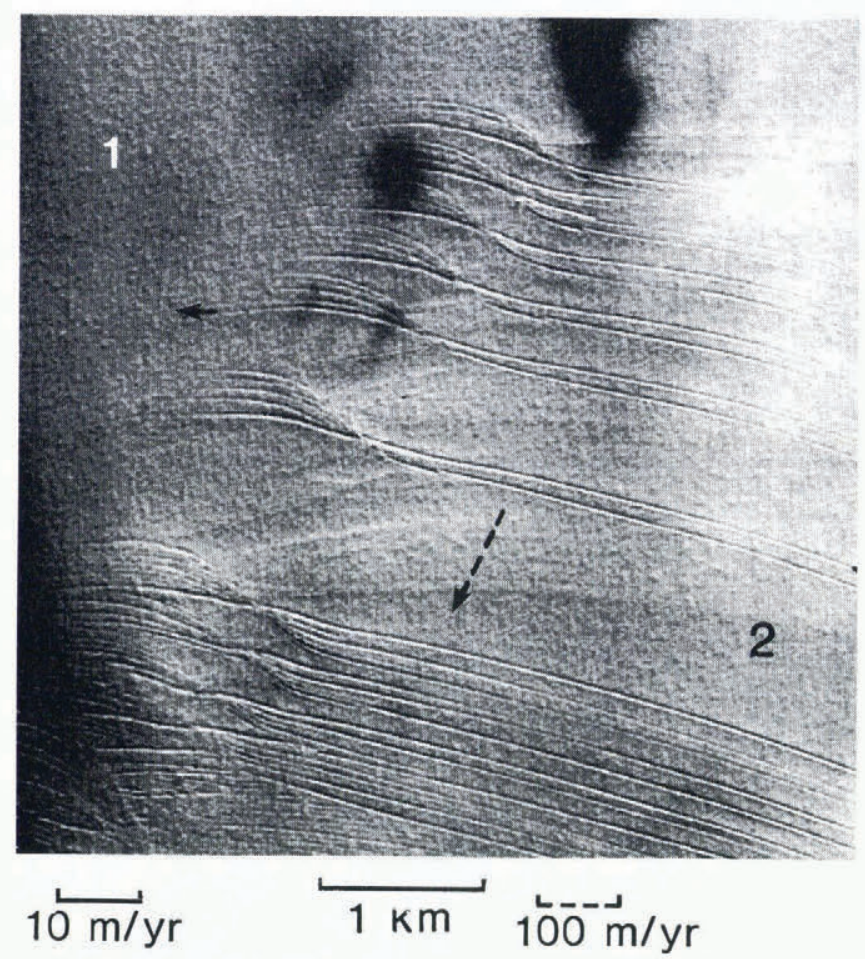

a

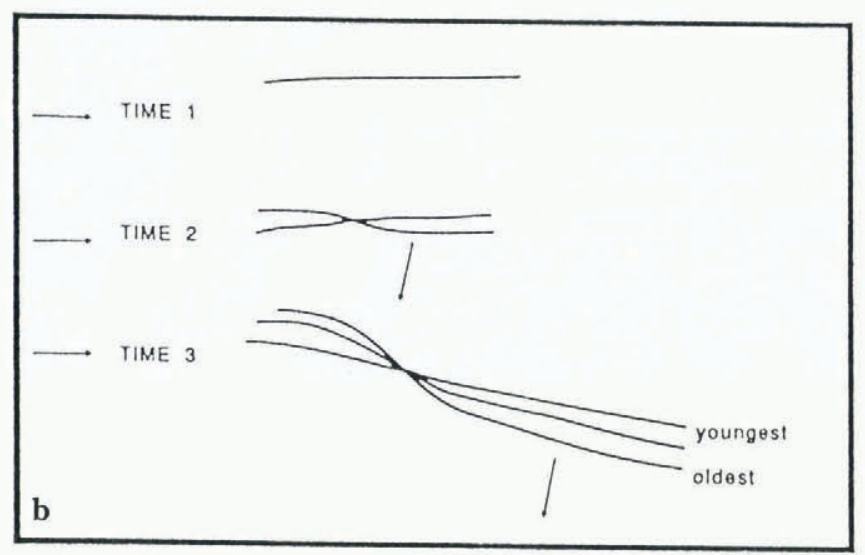

Fig. 3. a. Chromosomes at the up-glacial end of the heffalump, a right-lateral shear margin. The black areas at the upper right are cloud shadows. The unicorn (1) is moving at 3 myear $^{-1}$ and tributary B1b (2) is moving at 118 myear $^{-1}$ in the direction of the broken arrow. Scene width is $5.12 \mathrm{~km}$. b. Proposed model for chromosome development. pattern of crevasses is repeated for every shear margin observed on the imagery, except the ladder, as discussed below.

The shear margin on the other side of the unicorn (the heffalump) can be traced up-glacier to its origin. The shear margin begins with groups of intersecting crevasses reminiscent of separated "chromosomes" (Fig. 3a). Within the chromosomes, the shapes of individual crevasses can be understood using the model applied to shear margins. Against the slow-moving ridge, the leftmost end of each crevasse forms diagonally to the direction of shearing. To the right, in tributary $\mathrm{Blb}$, the crevasses are transverse, presumably associated with longitudinal stretching. At the boundary of these two regions, the crevasses are rotated clockwise with the rightlateral simple shear (Fig. 3b). There are as many as five generations of fresh-looking crevasses. There are also fainter, presumably older generations, such as the one passing through the number " 2 " in Figure $3 \mathrm{a}$. It is probably not possible to account for these patterns with a steady-flow model. A unique feature is that these freshlooking crevasses intersect at common points or nodes. There must be some feature in the ice that is causing this. Comparison of this imagery with uncontrolled aerial photography taken 4 years earlier (Vornberger and Whillans, 1986) shows no change in pattern, number or spacing of crevasses for each chromosome. Therefore, we conclude that this feature must be moving with the ice flow and is not fixed at the bed. Perhaps there are weak zones in the ice that influence where crevasses form.

Aircraft-based radar is another technique used to detect shear margins. There are radar returns caused by voids in the ice that are probably due to buried crevasses. A large density of returns from such scatterers is attributed to shear margins (Bentley and others, 1987). Interpretation and interpolation are involved in correlating zones of intense scatter between flight lines. In satellite imagery, shear margins are identified as zones of intense surface crevasses, which may differ from the location of buried crevasses. Thus, radar-derived shear margins may not align with those drawn based on the SPOT imagery.

Some of the shear margins detected here were also mapped by radar (Shabtaie and others, 1988; gates G1 and G2). The radar shows the same number of shear margins as the imagery at slightly different places and with different widths. For example, the heffalump is approximately $480 \mathrm{~m}$ wide in Shabtaie and others' gate G2, but $750 \mathrm{~m}$ wide in the imagery (Fig. 1b). This indicates that the radar and imagery show related features but with different areal extents. The imagery does not support all the correlations made between Shabtaie and others' flight lines. For example, the imagery and velocity vectors show that the ice at station 56 joins tributary B2, whereas Shabtaie and others inferred that the ice enters tributary Bl. It seems that Shabtaie and others misidentified other crevasse patches as shear margins.

\section{Lumps and warps}

Within the up-glacial end of the shear margin called the "snake", there is a train of small lumps (Fig. 4). The train of lumps crosses the shear margin diagonally. The lumps 


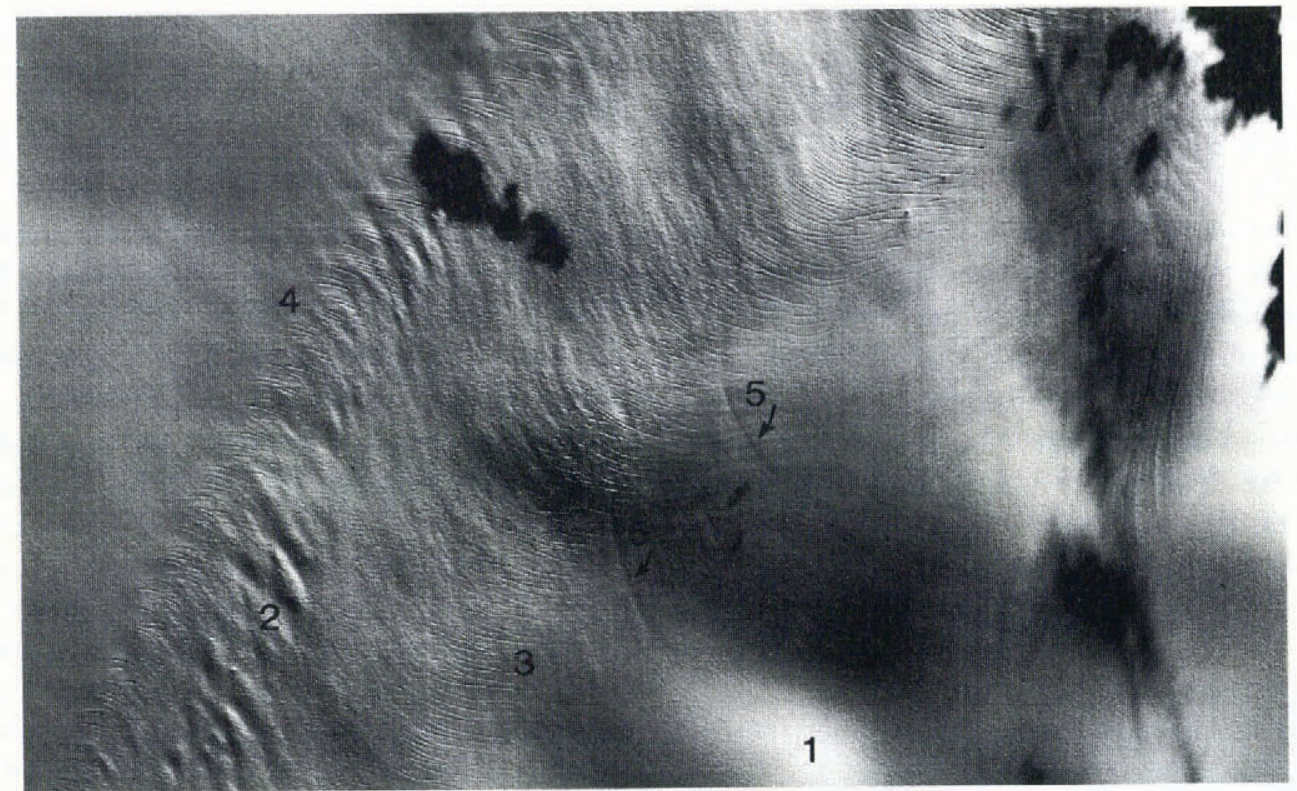

$1 . \overrightarrow{25} \mathrm{~km}$

Fig. 4. Up-glacial end of the snake. Mottles (1) occur on the righthand side of the image. A train of lumps (2) is located on the lefthand side. Hook-shaped en échelon trains of crevasses run from top center to lower left on either side of the snake (3 and 4 ). Two long curved crevasses of unclear origin occur in the middle of the figure (5). Dark spots are cloud shadows. Flow is toward the bottom of the figure. Scene width is $20.00 \mathrm{~km}$.

are about $1500 \mathrm{~m}$ long and $300 \mathrm{~m}$ wide and are spaced $600 \mathrm{~m}$ apart. The long axis of each lump is aligned at approximately right-angles to the direction of the most compressive stress in shear. The train of lumps seems to follow the direction of ice flow, which is westward (to the lower left, in the figure). Each lump may be a raft (a piece of inland ice incorporated with less distortion into the ice stream than at other sites of transition from inland ice to ice stream) or each lump may be a fold in the ice.

Two very large "warps" are shown in Figure 5. These are interpreted to be compressional buckles. These warps are $4 \mathrm{~km}$ long, $1.5 \mathrm{~km}$ wide and spaced at $8 \mathrm{~km}$. Like the lumps, the warps are aligned at approximately rightangles to the inferred direction of principal horizontal compressive stress associated with the shear margin. The down-glacial warp has irregular crevasses on its surface, which are reminiscent of irregular crevasses at the anticlinal summits of folds in the Ross Ice Shelf near the Bay of Whales (Zumberge and others, 1960).

Figures 4 and 5 show the onset of strong shearing. In this region, the shear margin is nearly ten times wider than elsewhere. The crevasses at the outer margins of this left-lateral shear zone are curved with a radius of curvature about five times larger than for crevasses in the shear margins of the dragon and heffalump. The radius of curvature of hook-shaped crevasses depends on the relative values of shearing and transport of ice perpendicular to the shear margin (Vornberger and Whillans, 1990). The larger radius of curvature for these crevasses indicates a stronger perpendicular component to ice flow, less shearing, or both. However, the absence of a chaotic zone favors the interpretation of reduced shearing in this region. Thus, this region seems to be near the start of a shear margin.

Near the southern shear margin of Ice Stream B1 (Fig. $6)$ is a distinctive ladder-like pattern. The rungs meet the flow traces that border them, the runners of the ladder, at an angle of about $60^{\circ}$. The orientation of the rungs is consistent with a formation by folding, as noted for the

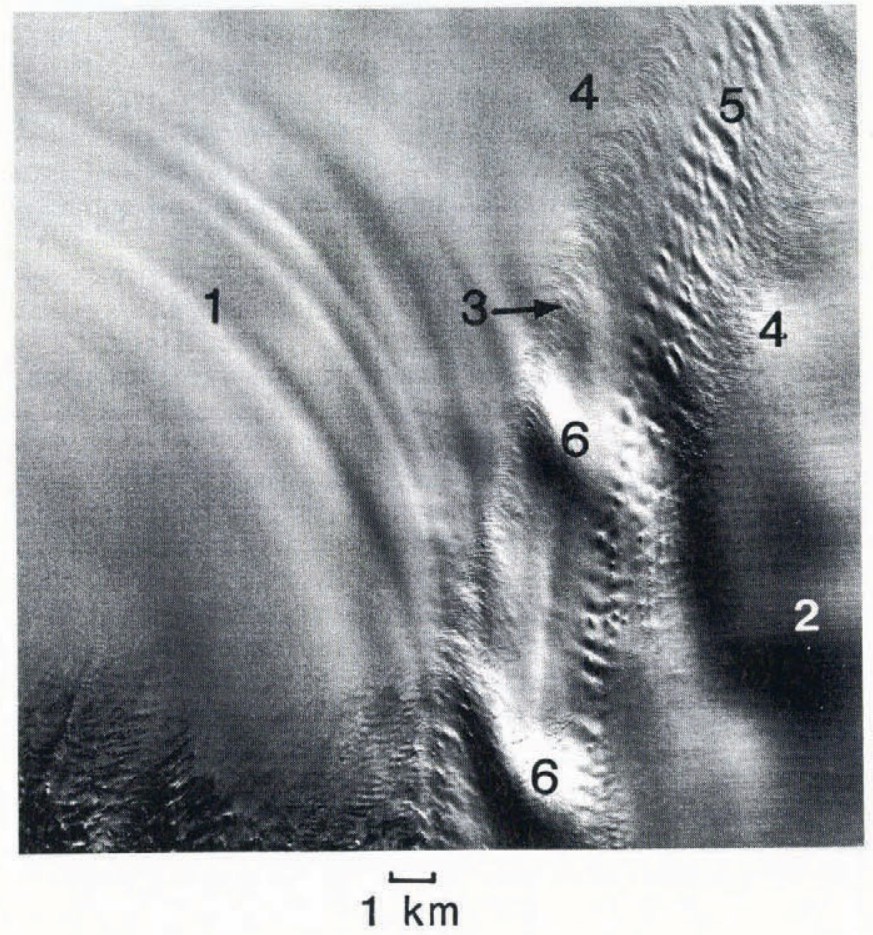

Fig. 5. Up-glacial end of the snake. Horsetail-shaped lineations on ridge $B / C(1)$ are shown. Tributary $B 2 b$ is at (2). A flow trace begins at (3). Lines of hook-shaped en échelon crevasses (4) occur on either side of the shear margin. Trains of lumps (5) occur within the shear margin. There are also two pronounced warps (6). Patches of fog occur in the lower left. Flow is toward the bottom of the figure. Scene width is $20.00 \mathrm{~km}$. 


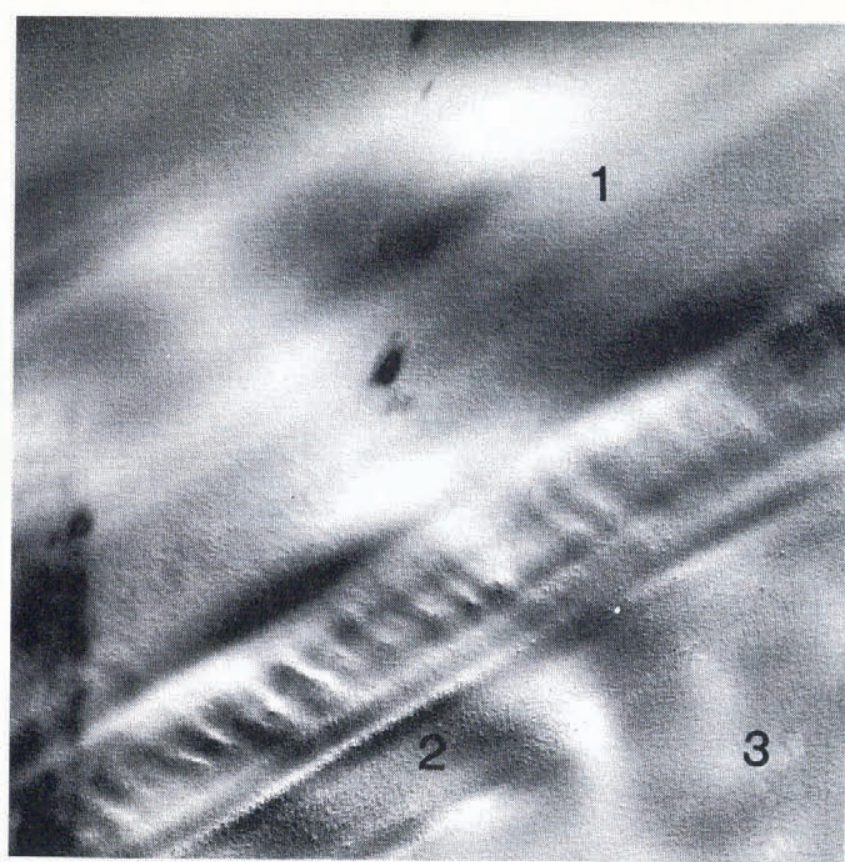

$1 \longdiv { \mathrm { km } }$

Fig. 6. The ladder at the southern shear margin to tributary B1a. Diffuse flow traces (1) in tributary B1a are moving at 368 myear $^{-1}$. The chaotic zone (2) is located adjacent to the ladder. Ridge $A \mid B(3)$ is in the lower right. Scene width is $15.0 \mathrm{~km}$.

lumps and warps above, or with time variation in the transition from ridge ice to ice-stream ice. In this case, the rungs would be considered as rafts or pieces of inland ice that have joined the ice stream in an irregular fashion and are now being advected with the ice flow.

\section{Flow traces}

Flow traces have been called "flowlines" (Crabtree and Doake, 1980; Swithinbank and Lucchitta, 1986; Bindschadler and others, 1987b), "flow bands" (Swithinbank and others, 1988), "suture zones" (Vornberger and Whillans, 1986), "septa" (Allen and others, 1960), "stream lines" (Stephenson and Bindschadler, 1990) and "flow stripes" (Casassa and Turner, 1991; Casassa and others, 1991). In mountainous regions, these features often trail away from junctions of tributaries (Swithinbank and others, 1988, p. 13-31). We think that none of these terms is a truly accurate and inclusive description. Flow traces are reminiscent of medial moraines in valley glaciers. But, on ice streams there can be no rock debris. This analogy suggests that flow traces may be formed at stationary, or nearly stationary, sources. The sources scar the ice and the scars are carried away with the ice flow. Thus, the age of a flow trace can be linked to its length and the speed of the ice.

Some large flow traces have sufficient topographic expression to be recognized in aerial photography and by aircraft terrain-clearance radar (Vornberger and Whillans, 1986; Shabtaie and others, 1987). In the case of the present imagery, the low sun elevation at the time of image acquisition $\left(18^{\circ}\right)$, together with digital enhancement, brings out even small slope changes. There are many more flow traces visible on the imagery than had previously been recognized.

It seems reasonable to adopt the hypothesis that flow traces originate at a point and trail away from it due to ice flow. In that case, flow traces are flowlines under conditions of steady flow. The relationship between flow traces and flowlines in an ice shelf has been investigated by Jezek (1984), MacAyeal (1989) and Casassa and others (1991).

Where flow traces can be compared with measured velocities, they are parallel to ice flow. This applies to the diffuse flow traces observed on tributary B1a (Fig. 1a) as well as to the more pronounced flow traces on tributary B2b (Fig. 1a). Elsewhere in Antarctica, flow traces align with valley walls or with measured velocities found on Byrd and Slessor Glaciers, the Filchner-Ronne Ice Shelf (Brecher, 1986; Lucchitta and Ferguson, 1986; Swithinbank and others, 1988) and the Rutford Ice Stream (Lucchitta and others, 1987).

Five hypotheses for the genesis of flow traces are suggested:

(i) Flow traces are old shear margins. A linkage with shear margins is suggested by the close similarity of flow traces with sutures formed between tributaries in other glaciers, and between tributaries B1 and B2 in Ice Stream B down-glacier of the area shown here (Vornberger and Whillans, 1986). The positive topographic relief may be because bulk density in a shear margin is small due to contained crevasses and the region stands high according to the Pratt model of isostasy, or because the region is weaker to horizontal compression (e.g. due to strain heating) and is squeezed upward.

(ii) Flow traces start with a disruption in flow over or around some basal feature. The disruption in flow causes crevasses, strain heating or the development of a special crystal texture or fabric that scars the ice. The flow traces are topographically high and preserved for the same reasons as in hypothesis (i).

(iii) Flow traces may be stretched-out mottles (Bindschadler and others, 1987a). Mottles are standing waves in the surface caused by basal irregularities or other flow resistance, such as sticky spots (Whillans and Johnsen, 1983). If the basal feature causing a mottle ceases to affect the flow, the mottle would be advected with the flow. Each flow trace represents a secular change in ice flow. When the mottle is carried into the ice stream, it becomes distorted by strong lateral compression and longitudinal extension, which are typical for ice streams and outlet glaciers, to form linear ridges that follow the flow. Each flow trace represents the cessation of the function of a sticky spot. The length of the trace is equal to the stretched dimension of the mottle.

(iv) Stephenson and Bindschadler (1990) proposed that "stream-lined flow" is due to "channeled subglacial hydrology", by which they presumably meant subglacial channels of water or mud. 


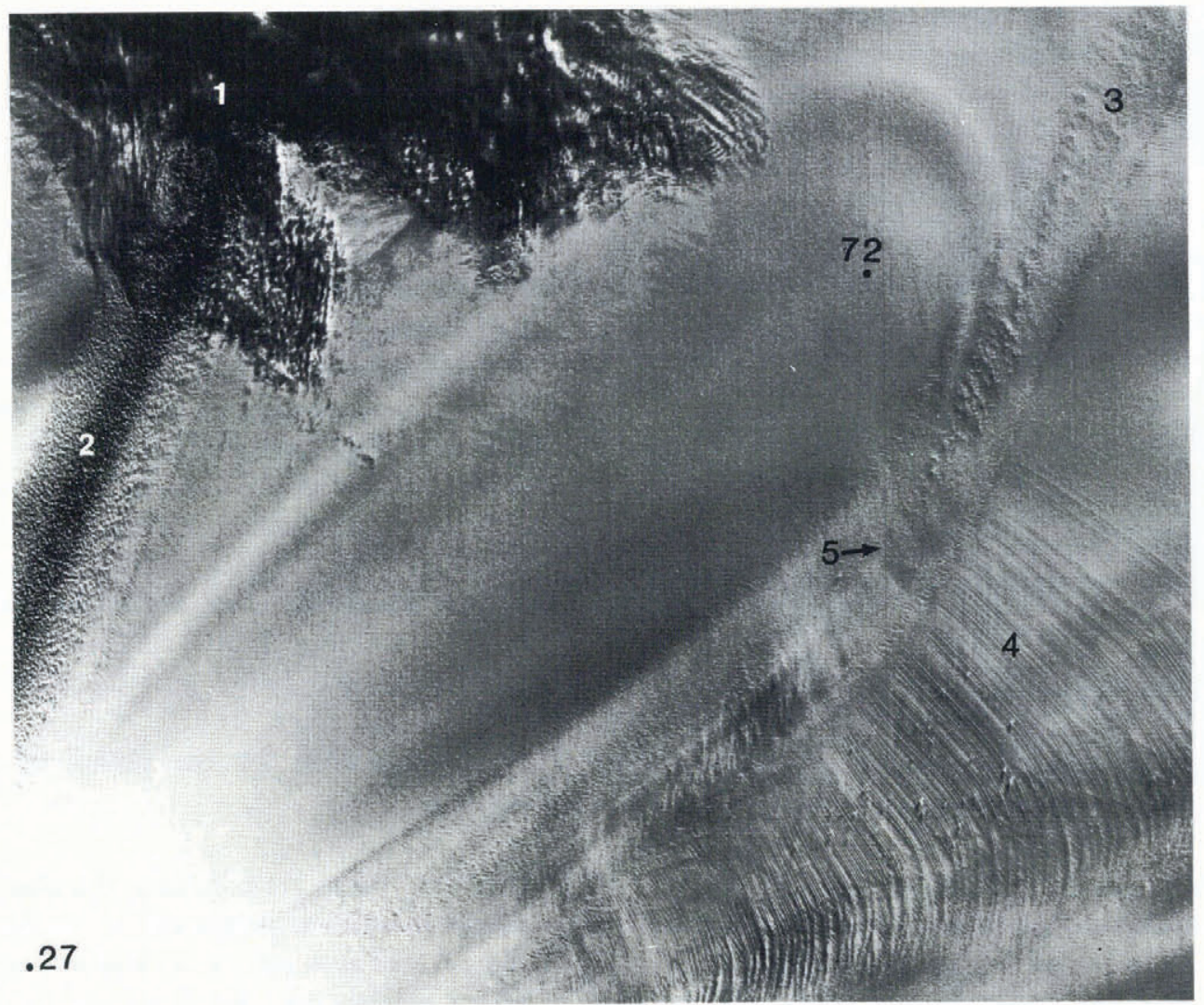

$\widetilde{1 \mathrm{~km}}$

Fig. 7. Curved lineation on the unicorn. Stations 27 and 72 , on the unicorn, are moving at 5 and 2 myear $^{-1}$, respectively. Dark fog (1) occurs in the upper left and partly covers the dark, linear chaotic zone of the dragon (2). The heffalump (3) is another shear margin. Tributary B1b (4) is moving at 118 myear $^{-1}$ toward the lower left. A flow trace (5) begins within the heffalump. Scene width is $25.0 \mathrm{~km}$.

(v) Flow traces are linked with fast flow and can be used to indicate rapidly flowing glaciers (Stephenson and Bindschadler, 1990). That is, there is some genetic link to fast flow.

It is possible to test some of these ideas. The last two hypotheses are most simply eliminated. Many or all of the glaciers in the Transantarctic Mountains are believed to be cold-based, and yet they contain stream lines or flow traces. Thus, subglacial water or mud is not a prerequisite for flow traces, and little credence is placed with hypothesis (iv). Also, Ice Stream C has flow traces (Stephenson and Bindschadler, 1990) and yet it is nearly stagnant. Small and presumably slowly moving glaciers in the Transantarctic Mountains have flow traces (Swithinbank and others, 1988, p. 13-31). These examples rule against hypothesis (v).

Hypothesis (iii) predicts that flow traces should have a finite length. However, on SPOT imagery, as well as on earlier aerial photography, the flow traces are very long and continuous. This invalidates the hypothesis. However, other features could be formed in this way (as stretched-out mottles). The short longitudinal ridges located down-glacier of the present imagery (Vornberger and Whillans, 1986) could be short segments of flow traces or stretched-out warps.

Hypothesis (i) is supported by the discovery of two flow traces that originate within the imagery. One of these is shown in Figure 7. The chaotic zone, called the heffalump, contains hummocky terrain at the upper end of Figure 7. This chaotic zone terrain is gradually transformed down-glacier into a long, linear flow trace. Another flow trace originates in the northern shear margin to tributary B2b, in the snake (Fig. 5).

Stephenson and Bindschadler (1990) found just the opposite, not that traces originate in a shear margin, but that a trace can evolve into a shear margin. Crevasses form along the path of a stream line that they believed originated at a bedrock feature, which relates to hypothesis (ii). The present imagery contains no examples of these phenomena.

There is nothing in the imagery to argue against hypothesis (i). The flow traces in Figures 5 and 7 begin in shear margins where there is transition from slow flow to faster, ice-stream flow. The physics involved in this transition is not known, but it may be associated with weakening of the ice or a change in basal lubrication. Perhaps the ice within the flow trace made the transition to fast ice-stream flow later than the ice to either side. The ice in the flow trace has thus been stretched and thinned less than neighboring ice. Largely by elimination, hypothesis (i) for the formation of flow traces is favored.

Flow traces can persist over long distances. "Flow bands" on the Ronne Ice Shelf can be traced for $700 \mathrm{~km}$ (Swithinbank and others, 1988). The flow trace, or "suture", caused by the merging of Ice Streams B1 and 
B2, just down-glacier of the image shown in Figure 7, has been mapped for $60 \mathrm{~km}$ (Vornberger and Whillans, 1986). Assuming that ice obeys the usual flow law for creep, the topographic relief in the traces should decay on a time-scale of about 10 years, due to horizontal gradients in lithostatic stress (the weight of ice above some datum). In 10 years, the ice moves less than $8 \mathrm{~km}$, yet the flow traces are very much longer.

Three possibilities are suggested for why flow traces decay slowly. These are:

(a) There may be transverse gradients in ice density. Closure of crevasses can trap pockets of air or snow, making the density smaller than normal. Zones of buried crevasses may underlie topographically high parts of flow traces. The relief could then be supported according to the Pratt model of crustal isostasy, in which material stands higher in inverse proportion to its density.

(b) Some rheologic model other than sub-solidus creep may be most important at shallow depths in ice streams. Perhaps the ice can support stresses elastically without creep. Ordinary creep may be impeded by the development of a suitable crystal-orientation fabric. The ice thus becomes rigid to the vertical shear stresses that support the ice features.

(c) There may be large transverse gradients in ice structure and hence in strength, such that the ice under topographic highs strains differently to horizontal normal stress than the ice located under the hollows. In particular, under lateral compression, a strip of weaker ice may be squeezed upward more than neighboring ice.

These hypotheses can be partially evaluated using the imagery. Hypothesis (a) predicts that each flow trace begins in a region of intense crevasses. However, the flow trace that begins in Figure 7 originates in a region with about as many crevasses as to either side. This evidence does not support a link between flow traces and crevasses. One may plead that the spatial resolution of the imagery is insufficient to detect all crevasses, so there could be more, but better bridged and sealed crevasses. Disregarding this special argument, hypothesis (a) probably is not the main reason for perseverance of flow traces.

The major flow trace, or suture, along the center of Ice Stream B (not shown here) disappears near the mouth of the ice stream, as the ice moves from a regime of lateral compression to one of lateral tension (Vornberger and Whillans, 1986). Perhaps when lateral compression is relieved, topographic highs sink into the glacier. Lateral compression seems to be necessary, an observation that favors hypothesis (c).

These analyses of the sites of flow-trace onset show that hypothesis (a) does not always apply. Thus, by elimination, hypotheses (b) and (c) are viable. Hypothesis (b) calls for special ice properties that have not been previously reported. Hypothesis (c) is favored.

\section{Lineations in slow ice}

There are other linear features on the imagery that are similar to flow traces, but are not obviously associated with ice flow, at least present-day flow. One example is the curved rib that crosses the unicorn (Fig. 7). This rib is nearly $1 \mathrm{~km}$ wide, more than $22 \mathrm{~km}$ long and changes azimuth by $135^{\circ}$. The speed of the ice in the unicorn is less than 2 mear $^{-1}$. The rib is unrecognizable in aerial photography or on radar soundings, presumably because its topographic expression is too small (say, less than $20 \mathrm{~m}$ ) to be detected by these techniques.

Other examples of such lineations occur at the upglacial end of ridge $\mathrm{B} / \mathrm{C}$ (horsetails in Figure 5). Speeds elsewhere on ridge $\mathrm{B} / \mathrm{C}$ are slow and this region is also believed to be moving slowly. The horsetail-like feature fans out and fades away to the left. This disappearance cannot be an effect of sun angle, because the horsetail fades away just where its orientation is perpendicular to solar illumination. The solar-illumination effect alone would make it more pronounced.

One explanation is that these features may be old flow traces or shear margins that were stranded due to a change in ice flow. However, it is not clear how the fanning out and fading away to the north of the horsetail feature in Figure 5 can be associated with a stranding. If these features are strand lines, they may be due to a thinning of the ice sheet. At present, the mass balance of the ice stream is negative (Whillans and Bindschadler, 1988), with the negative balance most pronounced at the ice-stream head (Whillans and others, 1987; Shabtaie and others, 1988). These linear features may mark the positions of the shear margins before the present thinning occurred.

A second possibility is that these features are compressional folds formed where faster ice impacts against slower ice (see Fig. 1b), rather like the bow wave generated in front of a moving boat. Such folds occur up-glacier of Crary Ice Rise (Bindschadler and others, 1987c). The folds near Crary Ice Rise are $107 \mathrm{~km}$ long and $24 \mathrm{~km}$ wide, and have a length to width ratio only twice those in Figure 5. The orientation of the lineations in Figure 5 is consistent with an origin due to compressional folding. However, at least at present, all measured velocities on the unicorn are very small.

\section{Bands of transverse crevasses}

Most crevasses in the body of the ice stream are transverse in orientation and occur in bands. On either side of each band are zones of more completely bridged crevasses. Figure 8 shows at least three such crevasse bands, as well as numerous drift plumes.

All the crevasses have snow bridges. The bridges form under blizzard conditions when horizontally drifting snow falls into open cracks or preferentially collects in negative relief elements caused by sagging of crevasse bridges. Growth of hoar crystals may also be important. The visibility of crevasses in photographs and satellite images is due to continued opening of the crevasse. The opening stretches the bridge and leads to sagging of the bridge under its own weight. Sometimes the bridge breaks and forms a fissure. Sags and wide fissures can be detected in the imagery. There can also be large, unbridged parts. Such holes can be detected regardless of the recent weather. However, blizzards may fill in sags and small fissures in the bridges, such that imagery acquired 


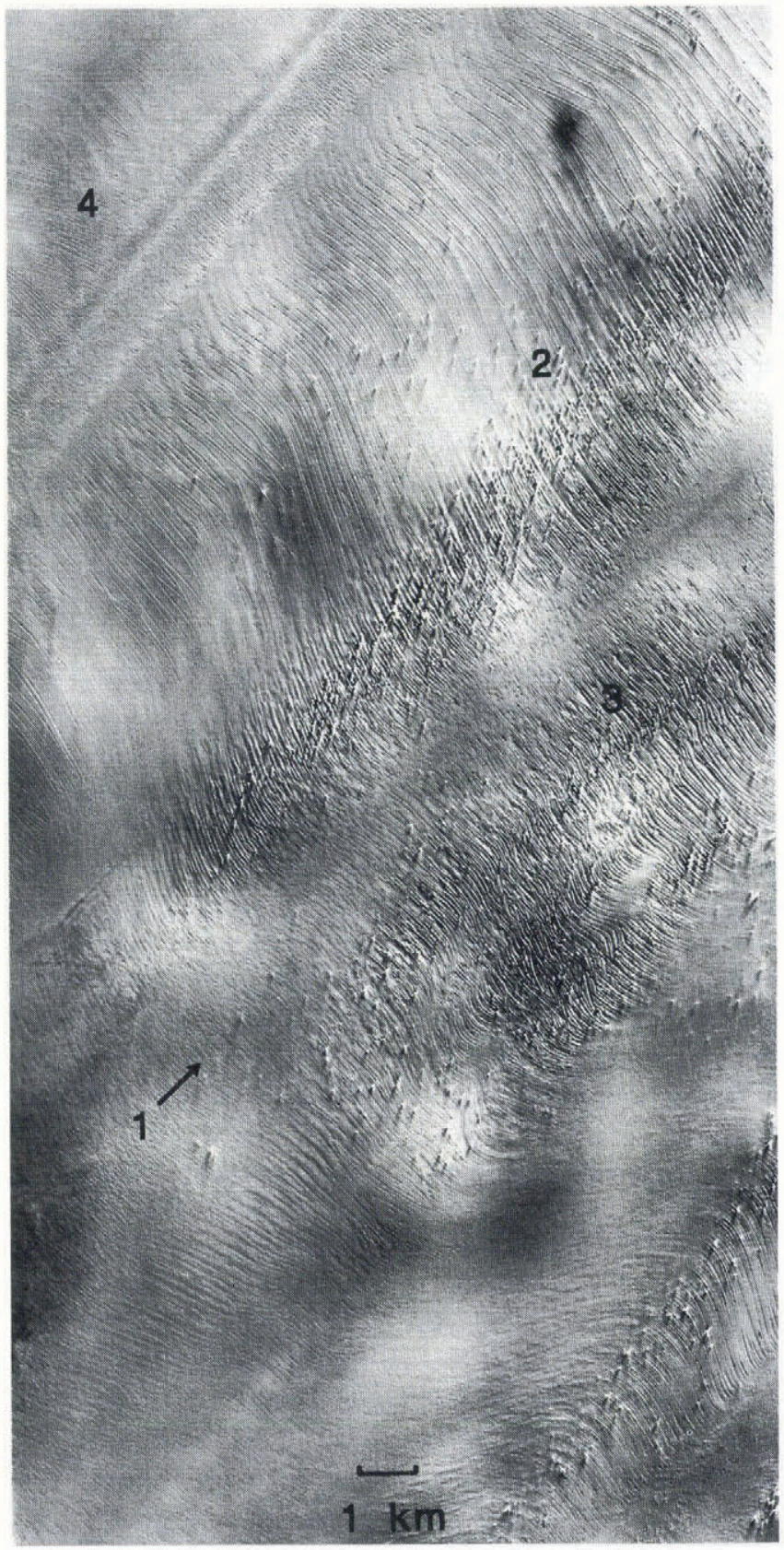

Fig. 8. Drift mounds (1), transverse crevasses (2 and 3) and a pronounced flow trace (4) within tributary B2. Scene width is $19.5 \mathrm{~km}$.

immediately after a blizzard would show fewer crevasses.

Four processes are suggested for the cause of transverse crevasse bands:

(i) Strain rates may be larger in certain longitudinal zones and open crevasses more quickly, making them more evident.

(ii) Snow may accumulate preferentially in the zones between the crevasse bands and bury crevasses.

(iii) Each band of crevasses may be due to a point source that creates crevasses at the up-glacial end of the crevasse band.

(iv) Each band may overlie ice whose structure makes it more prone to crevasse formation.
Vornberger and Whillans (1986), in their study of aerial photographs, were unable to determine which process dominates. With the present imagery, it is possible to readdress this question. We find evidence to disfavor the dominance of the first three processes.

According to the first process, strain rates should be larger in the crevasse bands than in neighboring ice. This means that the crevasse band is stretched more than the ice between crevasse bands. Such differential stretching should rotate the ends of the crevasses, such that the crevasses in each band become progressively more concave up-glacier. Figure 8 shows no consistent direction of curvature to the crevasses. This disfavors process (i).

The second process is evaluated by taking advantage of the orientation of drift plumes. Drift plumes form downwind of standing eddies in the wind field (Bromwich and others, 1990). The eddies are anchored over holes in crevasse bridges. Drift plumes develop because of relatively small wind speeds in the lee of the eddy. Sometimes the hole becomes sealed, but the plume continues to exist until it is ablated or buried by normal snow accumulation. Many such relict plumes occur in Figure 8. Drift plumes indicate the direction of wind transport during major blizzards, which is from $10^{\circ}$ clockwise from the top of the figure. The observed orientation of crevasse bands is more nearly aligned with flow traces $\left(45^{\circ}\right.$ clockwise from the top of the figure) and hence with ice flow. Crevasse banding does not seem to be closely associated with wind drift, and thus process (ii) may be discounted.

The third process is evaluated by considering how groups of crevasses often develop on other glaciers. Strainrate differences arise if the glacier passes over a bed that offers non-uniform drag. Tension occurs just up-glacier of an obstruction (or sticky spot), such as a basal hill or resistive site. This tension arises because the ice is held back at depth and, to maintain discharge, the ice flow adjusts by increasing speed in the upper part of the ice sheet. These speeds reach a maximum over the obstruction. Theory and observation in inland ice shows that the region of tension extends up-flow from the obstruction for $1-3 \mathrm{~km}$ (Whillans and Johnsen, 1983). There is lateral spreading of flow up-glacier of an obstruction that limits the up-glacial extent of crevasses. Stephenson and Bindschadler (1990) reported that crevasses are usually found on the crests of surface mottles on Ice Streams D and E. This is as expected for the effect of a basal obstruction. However, on Ice Stream B the crevasse bands identified on the SPOT imagery and aerial photography are tens of kilometers long, which is much longer than can be associated with zones of tension up-glacier of basal obstructions. Moreover, unlike other crevasse patches, the crevasse bands are much longer than they are wide. Furthermore, there is nothing special in the basal topography reported by Retzlaff and others (1993) at the onset of the crevasse bands. It is difficult to account for the crevasse bands as due to a basal sticky spot, as called for by process (iii).

The concept for process (iv) is much like that for hypothesis (i) for flow traces. Certain longitudinal zones in ice streams, marked with crevasse bands, have an iceorientation fabric or ice temperature that makes them 


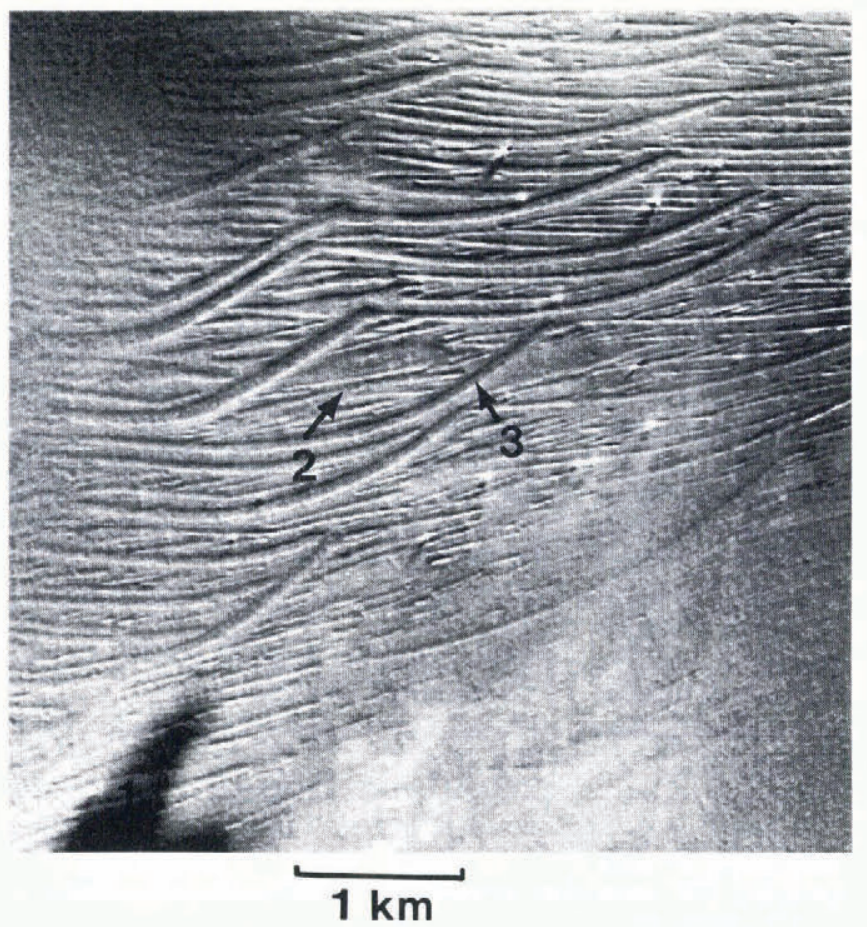

Fig. 9. Seagulls. The dark patch (1) is a cloud shadow. Older crevasses (2) can be distinguished from newer crevasses (3). Several drift mounds are evident. Scene width is $5.12 \mathrm{~km}$.

stronger to longitudinal tension. Thus, the ice under crevasse bands is a stress guide and carries a larger tensile stress. By elimination, process (iv) is favored.

An unusual set of intersecting crevasses occurs upglacier of tributary Blb (Fig. 9). Most crevasses elsewhere on the image are transverse or in shear margins, but in Figure 9 there are at least two generations of crevasses. An older generation of crevasses is composed of closely spaced, straight crevasses. A younger, cross-cutting generation contains more widely spaced, curved crevasses. The younger set is reminiscent of simple drawings of flying seagulls. We have been unable to model this group of crevasses, except to suggest that there has been a time change in ice flow.

Another set of unusual crevasses occurs in the center of Figure 4. They are longitudinal and distinctly curved. They are spaced about ten times wider than the perpendicular set of transverse crevasses that crosses part of them. We have no explanation for their existence.

\section{Mottles}

Undulations are commonly observed on slowly flowing inland ice. On satellite imagery, the undulations cause alternating dark and bright patches, or mottles. Examples occur in the upper middle part of Figure la. Where mottles have been studied in detail, such as near Byrd Station, Antarctica (Whillans and Johnsen, 1983), and Dye 3, Greenland (Whillans and others, 1984), the spacing of mottles is about $10 \mathrm{~km}$. The distribution of mottles appears to be isotropic. Modeling shows that they can be accounted for by normal inland-ice style of flow over bed irregularities (Whillans and Johnsen, 1983; Whillans and Jezek, 1987). An orientation fabric to the mottled pattern can occur (Swithinbank, 1988). This can be due to a corresponding fabric in the bed or to a bias associated with the direction of solar illumination. In Figure $1 \mathrm{a}$, mottles are about $2.5 \mathrm{~km}$ wide and spaced $5 \mathrm{~km}$ apart, the mottles seem to be randomly distributed and they occur on ice moving at relatively large speeds (about $186 \mathrm{~m}$ year $^{-1}$ ). The imagery suggests that the processes generating mottles in slowly moving ice also act in fast ice.

There are mottles within Ice Stream Bla (Fig. la). That tributary is flowing at an even faster speed $\left(368 \mathrm{~m}\right.$ year $\left.{ }^{-1}\right)$. The mottles occur within the diffuse-flow traces with a spacing of $6 \mathrm{~km}$. They seem to be unrelated to the flow traces. None of the mottles bears any discernible relationship to bed topography as mapped by Retzlaff and others (1993), but they could be associated with variations in subglacial lubrication.

\section{SUMMARY}

This work confirms the findings of previous authors that there is an enormous amount of information on ice flow that can be derived from satellite imagery over ice sheets. This is due to the fine radiometric and spatial resolution of the satellite sensors, combined with digital enhancement to emphasize very subtle surface features. We have shown that, for the interior of the West Antarctic ice sheet, the surface features are flow effects and are not due to surface snow type or the effects of melting. Many of the observed flow features are spatially so broad and of such low relief that they cannot be detected by any method other than by satellite imagery.

The images are not easy to obtain. This is largely because of untimely cloud cover. Estimates of cloud cover by SPOT Image Corporation are inaccurate and tend to be an overestimation. This makes it difficult to select appropriate imagery for purchase.

The present imagery covers the onset region of Ice Stream B. Our interpretation shows that the ice stream begins as several tributaries that later coalesce. Thus, the switch from inland-ice flow to ice-stream flow occurs separately at different locations. Shear margins, which separate fast flow from slow flow, can be initially wide but narrow down-glacier. One shear margin, the heffalump, begins with a geometrically simple group of crevasses called the chromosomes that indicate that shearing is associated with a weakness that travels with the ice. The imagery alone is not sufficient to deduce the mechanics of ice-stream motion, but observations such as these should be of help in future deductions.

An objective of the present work is to contribute to an understanding of the genesis of features that are observed in satellite imagery. The genetic possibilities for flow traces, other lineations, bands of transverse crevasses, shear margins, mottles, and lumps and warps are organized, and certain possibilities eliminated. In particular:

Shear margins are readily identified on the imagery. Elements of the shear margin follow a pattern described by the Vornberger and Whillans (1990) model. In one region, the chromosomes, the crevasses have not been forming at a steady rate. 
Two large warps were identified on the imagery near the up-glacial end of the snake. The warps are interpreted to be compressional buckles. In the same region, trains of lumps follow the direction of ice flow. Each lump is a piece of inland ice or a fold in the ice. Each warp and lump is aligned at approximately right-angles to the inferred direction of principal horizontal compressive stress. Crevasses with a large radius of curvature are associated with the shear margin. This indicates slower shearing than farther down-glacier. The region is interpreted to be the onset of a shear margin.

Five hypotheses for the genesis of flow traces are proposed. Evidence from the satellite imagery favors the view that flow traces are formed in shear margins.

Other lineations are observed on the imagery. These bear no obvious association with present ice flow. Two explanations are provided. They may be old flow traces or shear margins that were stranded due to a change in flow. Another possibility is that these features are compressional folds formed where faster ice impacts against slower ice.

Most of the crevasses on the ice streams are transverse and occur in bands. Several causes of transverse crevasse bands are proposed, but the evidence favors that ice structure or temperature is responsible for crevasse location.

Mottles are observed on ice moving at relatively fast speeds, indicating that the processes generating mottles in slowly moving ice also act in fast ice.

The SPOT $10 \mathrm{~m}$ panchromatic imagery has worked well in mapping large-scale glacial features. The imagery provides a much larger-scale view of the ice stream than has been possible with aerial photography. New insights into the flow of ice streams have been developed.

\section{ACKNOWLEDGEMENTS}

J. Bossler (Center for Mapping, OSU) provided the equipment for reading and displaying the SPOT figures. R. Bindschadler (NASA/Goddard Space Flight Center) provided the facilities to produce Figure 1a. C.J. van der Veen (Byrd Polar Research Center) provided a helpful review of the manuscript, as did the two anonymous reviewers and D. R. MacAyeal. This work was sponsored by U.S. National Science Foundation grant No. DPP8918708. This is Byrd Polar Research contribution No. 804.

\section{REFERENCES}

Allen, C. R., W. B. Kamb, M. F. Meier and R. P. Sharp. 1960. Structure of the lower Blue Glacier, Washington. J. Geol., 68(6), 601-625.

Bentley, C.R. and 6 others. 1987. Remote sensing of the Ross ice streams and adjacent Ross Ice Shelf, Antarctica. Ann. Glaciol., 9, 20-29.

Bindschadler, R.A. and T.A. Scambos. 1991. Satellite-image-derived velocity field of an Antarctic ice stream. Science, 252(5003), 242-246.

Bindschadler, R. A., K. G. Jezek and J. Crawford. 1987a. Glaciological investigations using the synthetic aperture radar imaging system. Ann. Glaciol., 9, 11-19.

Bindschadler, R. A., S. N. Stephenson, D. R. MacAyeal and S. Shabtaie. 1987b. Ice dynamics at the mouth of Ice Stream B, Antarctica. J. Geophys. Res., 92(B9), 8885-8894.

Bindschadler, R. A., D.R. MacAyeal, S.N. Stephenson, P. L. Vornberger and E.P. Roberts. 1987c. Transient behavior of Ice Stream B and Crary Ice Rise, West Antarctica. Antarct. J. U.S., 22(5), 66-67.

Brecher, H.H. 1986. Surface velocity determination on large polar glaciers by aerial photogrammetry. Ann. Glaciol., 8, 22-26.

Bromwich, D., T. R. Parish and C. A. Zorman. 1990. The confluence zone of the intense katabatic winds at Terra Nova Bay, Antarctica, as derived from airborne sastrugi surveys and mesoscale numerical modeling. J. Geophys. Res., 95(D5), 5495-5509.

Casassa, G. and J. Turner. 1991. Dynamics of the Ross Ice Shelf. Eos, 72(44), 473-481.

Casassa, G., K.C. Jezek, J. Turner and I.M. Whillans. 1991. Relict flow stripes on the Ross Ice Shelf. Ann. Glaciol., 15, 132-138.

Crabtree, R. D. and C.S.M. Doake. 1980. Flow lines on Antarctic ice shelves. Polar Rec., 20(124), 31-37.

Ferrigno, J.G. and W.G. Gould. 1987. Substantial changes in the coastline of Antarctica revealed by satellite imagery. Polar Rec., 23(146), 577-583.

Jacobs, S. 1988. Subsurface currents in the southeast Ross Sea. Antarct. J. U.S., $23(5), 80-82$.

Jensen, J.R. 1986. Introductory digital image processing. New Jersey, Prentice-Hall.

Jezek, K.C. 1984. Recent changes in the dynamic condition of the Ross Ice Shelf, Antarctica. 7. Geophys. Res., 89(B1), 409-416.

Jezek, K. C., D.J. Cavalieri and A. Hogan. 1990. Antarctic ice sheet brightness temperature variations. CRREL Monogr. 90-1, 217-223.

Jezek, K.C. and 6 others. 1991. Comparison between SMMR and SSM/I passive microwave data collected over the Antarctic ice sheet. Columbus, $\mathrm{OH}$, Byrd Polar Research Center. (BPRC Technical Report 91-03.)

Lucchitta, B. K. and H.M. Ferguson. 1986. Antarctica: measuring glacier velocity from satellite images. Science, 234(4780), 1105-1108.

Lucchitta, B. K., J. Bowell, K. L. Edwards, E. M. Eliason and H. M. Ferguson. 1987. Multispectral Landsat images of Antarctica. U.S. Geol. Surv. Bull. 1696.

MacAyeal, D. R. 1989. Ice-shelf response to ice-stream discharge fluctuations: III. The effects of ice-stream imbalance on the Ross Ice Shelf, Antarctica. 7. Glaciol., 35(119), 38-42.

McDonald, J. 1990. Use of TRANSIT satellites to study the West Antarctic ice sheet. (M.S. thesis, Ohio State University.)

Martin, P.J. 1976. Ridges on Antarctic ice rises. J. Glaciol., 17(75), 141144.

Milne, A.A. 1926. Winnie-the-Pooh. London, Methuen Children's Books. Orheim, O. 1978. Glaciological studies by Landsat imagery of perimeter of Dronning Maud Land, Antarctica. Nor. Polarinst. Skr. 169, 69-80.

Orheim, O. and B.K. Lucchitta. 1987. Snow and ice studies by Thematic Mapper and multispectral scanner Landsat images. Ann. Glaciol., 9, $109-118$.

Orheim, O. and B. K. Lucchitta. 1988. Numerical analysis of Landsat Thematic Mapper images of Antarctica: surface temperatures and physical properties. Ann. Glaciol., 11, 109-120.

Retzlaff, R., N. Lord and C. R. Bentley. 1993. Airborne-radar studies: Ice Streams A, B and C, West Antarctica. J. Glaciol., 39(133), 495506.

Shabtaie, S. and C. R. Bentley. 1988. Ice-thickness map of the West Antarctic ice streams by radar sounding. Ann. Glaciol., 11, 126-136.

Shabtaie, S., I. M. Whillans and C. R. Bentley. 1987. The morphology of Ice Streams A, B, and C, West Antarctica, and their environs. $\mathcal{F}$. Geophys. Res., 92(B9), 8865-8883.

Shabtaie, S., C. R. Bentley, R. A. Bindschadler and D. R. MacAyeal. 1988. Mass-balance studies of Ice Streams A, B, and C, West Antarctica, and possible surging behavior of Ice Stream B. Ann. Glaciol., 11, 137-149.

SPOT Image Corporation. 1987. Extended life predicted for SPOT. Spotlight, 1(4), 6.

Stephenson, S. N. and R.A. Bindschadler. 1990. Is ice-stream evolution revealed by satellite imagery? Ann. Glaciol., 14, 273-277.

Swithinbank, C. 1988. Satellite image atlas of glaciers of the world. Antarctica. U.S. Geol. Surv. Prof. Pap. 1386-B.

Swithinbank, C. and B. K. Lucchitta. 1986. Multispectral digital image mapping of Antarctic ice features. Ann. Glaciol., 8, 159-163. 
Swithinbank, C., P. McClain and P. Little. 1977. Drift tracks of Antarctic icebergs. Polar Rec., 18(116), 495-501.

Swithinbank, C., K. Brunk and J. Sievers. 1988. A glaciological map of Filchner-Ronne Ice Shelf, Antarctica. Ann. Glaciol., 11, 150-155.

Tseng, Y.-H. 1992. Digital photogrammetric approach to ice-flow determination in Antarctica. Columbus, OH, Ohio State University. Department of Geodetic Science and Surveying. (Report 422.)

Vornberger, P. L. and I.M. Whillans. 1986. Surface features of Ice Stream B, Marie Byrd Land, West Antarctica. Ann. Glaciol., 8, 168170.

Vornberger, P. L. and I.M. Whillans. 1990. Crevasse deformation and examples from Ice Stream B, Antarctica. 7. Glaciol., 36(122), 3-10.

Whillans, I. M. and R.A. Bindschadler. 1988. Mass balance of Ice Stream B, West Antarctica. Ann. Glaciol., 11, 187-193.

Whillans I. M. and K. C. Jezek. 1987. Folding in the Greenland ice sheet. F. Geophys. Res., 92(B1), 485-493.

Whillans, I. M. and S.J. Johnsen. 1983. Longitudinal variations in glacial flow: theory and test using data from the Byrd Station strain network, Antarctica. F. Glaciol., 29(101), 78-97.

Whillans, I.M. and C.J. van der Veen. 1993. New and improved determinations of velocity of Ice Streams B and C, Antarctica. F. Glaciol., 39(133), 483-490.

Whillans, I. M., K. C. Jezek, A. R. Drew and N. Gundestrup. 1984. Ice flow leading to the deep core hole at Dye 3, Greenland. Ann. Glaciol., 5, 185-190.

Whillans, I. M., J. Bolzan and S. Shabtaie. 1987. Velocity of Ice Streams B and C, Antarctica. 7. Geophys. Res., 92(B9), 8895-8902.

Williams, R.S., Jr and J.G. Ferrigno. 1988. Landsat images of Antarctica. U.S. Geol. Surv. Prof. Pap. 1386-B, 139-145.

Williams, R.S., Jr, T.K. Meunier and J.G. Ferrigno. 1983. Blue ice, meteorites and satellite imagery in Antarctica. Polar Rec., 21(134), 493-496.

Zumberge, J.H., M. Giovinetto, R. Kehle and J. Reid. 1960. Deformation of the Ross Ice Shelf near the Bay of Whales, Antarctica. I.G.Y. Glaciol. Rep. Ser. 3.

The accuracy of references in the text and in this list is the responsibility of the authors, to whom queries should be addressed. 